\title{
PENGARUH MEDIA SIMULASI TERHADAP KETERAMPILAN BERPIKIR KRITIS PADA KONSEP FLUIDA STATIS
}

\author{
Nindya Novianti, Erina Hertanti*, Taufiq Al Farizi \\ Pendidikan Fisika, Universitas Islam Negeri Syarif Hidayatullah \\ *Email: erina.hertanti@uinjkt.ac.id
}

DOI: http://dx.doi.org/10.29303/jpft.v5i2.1168

\begin{abstract}
The study was a quasi-experimental research involving nonequivalent control group design. This study aimed at investigating the impact of simulation media toward students'critical thinking in static fluid concept at SMAN 10 South Tangerang. The research was conducted from January $28^{\text {th }}$ until February $13^{\text {th }}$, 2019. The technique used was purposive sampling to determine research subjects. The subjects were consisting of XI IPA 2 as an experiment class and XI IPA 1 as a control class. The data were obtained from test in the form of 10 essays questions and questionnaire. Significantly, the post test data showed that learning by using simulation media influenced toward students' critical thinking skill. Simulation media obtained positive response with very good category (86\%).
\end{abstract}

Keywords: simulation media; static fluid; critical thinking skill

\section{PENDAHULUAN}

Kurikulum 2013 mengamanatkan esensi pendekatan saintifik dalam proses pembelajaran. Dalam hal ini proses pembelajaran dipadankan dengan suatu proses ilmiah yang dibangun berdasarkan serangkaian aktivitas saintis melalui kegiatan mengamati, menanya, mengumpulkan informasi, mengasosiasi dan mengkomunikasikan (Peraturan Kemendikbud, 2013).

Namun, dari kelima kegiatan tersebut, pada kegiatan mengasosiasi guru cenderung mengalami kesulitan. Padahal kegiatan mengasosiasi dapat menjadi titian siswa dalam mengembangkan suatu keterampilan, salah satunya keterampilan berpikir kritis (Wuri et al. 2014). Artinya, diperlukan upaya yang mampu memfasilitasi siswa melakukan aktivitas guna mengasah keterampilan berpikir kritisnya pada kegiatan mengasosiasi tersebut.

Umumnya upaya yang dilakukan pada kegiatan mengasosiasi, yaitu guru meminta siswa untuk berdiskusi. Namun, kegiatan diskusi tersebut cenderung pasif, terlihat dari aktivitas sebagian siswa yang hanya mendengarkan pendapat, berbicara dan bercanda dengan teman (Iis, 2015). Pada penelitian ini fokus kegiatan mengasosiasi diarahkan pada pelibatan berbagai indera siswa melalui penggunaan media simulasi. Dalam hal ini, media simulasi didesain untuk meminta siswa melakukan berbagai kegiatan.

Hal ini didukung oleh pendapat Linn \& Gronlund (2008), ketika siswa melakukan berbagai kegiatan seperti membandingkan, menghubungkan, memberikan alasan, menganalisis dan menyimpulkan, artinya siswa dapat melakukan aktivitas yang mengasah keterampilan dalam berpikir, salah satunya keterampilan berpikir kritis.

Pada penelitian ini media simulasi akan menyajikan beberapa percobaan guna melatih keterampilan berpikir kritis siswa, seperti memberikan penjelasan, mengidentifikasi, atau membuat kesimpulan. Sementara keterampilan berpikir kritis akan diasah dan dikembangkan pada mata pelajaran fisika, yaitu konsep fluida statis. Syarifah (2015) dalam penelitiannya menyatakan, salah satu konsep fisika yang dapat mengembangkan keterampilan berpikir kritis, yaitu fluida statis. 


\section{METODE PENELITIAN}

Penelitian ini dilaksanakan di SMAN 10 Tangerang Selatan dengan menggunakan metode kuasi eksperimen (Quasi Experimental) dan menggunakan desain nonequivalent control group. Penelitian ini dilakukan di SMAN 10 Tangerang Selatan. Populasi dalam penelitian ini adalah seluruh siswa SMAN 10 Tangerang Selatan sedangkan sampel dalam penelitian ini adalah kelas XI IPA 2 sebagai kelas eksperimen dan kelas XI IPA 1 sebagai kelas control. Dalam penelitian ini, kedua kelas akan diberi perlakuan yang berbeda. Kelas eksperimen diberikan perlakuan berupa pembelajaran menggunakan media simulasi, sedangkan kelas kontrol diberikan perlakuan berupa pembelajaran konvensional.

Dalam penelitian ini, pengumpulan data dilakukan dengan menggunakan dua teknik, yaitu pemberian tes Essay dan angket. Pemberian tes Essay untuk mengetahui keterampilan berpikir kritis siswa. Sementara angket diberikan untuk mengetahui respon siswa terhadap penggunaan media simulasi (Sugiyono, 2011). Selanjutnya, data analisis secara kuantitatif dengan uji reliabilitas, taraf kesukaran, daya pembeda, uji normalitas data dan uji n-gain.

\section{HASIL DAN PEMBAHASAN}

\section{A. Hasil Penelitian}

Hasil Pretest dan posttest kelas eksperimen dan kelas kontrol dalam penelitian ini dapat dilihat pada Tabel 1 dan Tabel 2.

Tabel 1. Rekapitulasi Hasil Pretest Kelas Eksperimen dan Kelas Kontrol.

\begin{tabular}{|c|c|c|}
\hline \multirow{2}{*}{$\begin{array}{c}\text { Pemusatan } \\
\text { dan } \\
\text { Penyebaran } \\
\text { Data }\end{array}$} & \multicolumn{2}{|c|}{ Pretest } \\
\hline & $\begin{array}{c}\text { Kelas } \\
\text { Eksperimen }\end{array}$ & $\begin{array}{c}\text { Kelas } \\
\text { Kontrol }\end{array}$ \\
\hline $\begin{array}{c}\text { Nilai } \\
\text { Terendah }\end{array}$ & 20,00 & 24,00 \\
\hline $\begin{array}{c}\text { Nilai } \\
\text { Tertinggi }\end{array}$ & 62,00 & 64,00 \\
\hline
\end{tabular}

\begin{tabular}{ccc}
\hline $\begin{array}{c}\text { Pemusatan } \\
\text { dan }\end{array}$ \\
\cline { 2 - 3 } $\begin{array}{c}\text { Penyebaran } \\
\text { Data }\end{array}$ & $\begin{array}{c}\text { Pretest } \\
\text { Eksperimen }\end{array}$ & $\begin{array}{c}\text { Kelas } \\
\text { Kontrol }\end{array}$ \\
\hline Rata-rata & 41,24 & 45,30 \\
\hline Modus & 35,35 & 48,70 \\
\hline Median & 38,00 & 46,00 \\
\hline $\begin{array}{c}\text { Standar } \\
\text { Deviasi }\end{array}$ & 11,05 & 8,91 \\
\hline
\end{tabular}

Tabel 2. Rekapitulasi Hasil Posttest Kelas Eksperimen dan Kelas Kontrol.

\begin{tabular}{ccc}
\hline $\begin{array}{c}\text { Pemusatan } \\
\text { dan } \\
\begin{array}{c}\text { Penyebaran } \\
\text { Data }\end{array}\end{array}$ & $\begin{array}{c}\text { Kelas } \\
\text { Eksperimen }\end{array}$ & $\begin{array}{c}\text { Kelas } \\
\text { Kontrol }\end{array}$ \\
\cline { 2 - 3 } $\begin{array}{c}\text { Nilai } \\
\text { Terendah }\end{array}$ & 54,00 & 54,00 \\
\hline $\begin{array}{c}\text { Nilai } \\
\text { Tertinggi }\end{array}$ & 90,00 & 90,00 \\
\hline Rata-rata & 75,57 & 75,57 \\
\hline Modus & 77,50 & 77,50 \\
\hline Median & 76,00 & 76,00 \\
\hline $\begin{array}{c}\text { Standar } \\
\text { Deviasi }\end{array}$ & 7,55 & 7,55 \\
\hline
\end{tabular}

Nilai rata-rata pretest kelas eksperimen $(41,24)$ lebih rendah dibandingkan dengan nilai rata-rata pretest kelas kontrol $(45,30)$. Pada kelas kontrol mengalami kenaikan nilai rata-rata dengan selisih pretest dan posttest sebesar 21, sedangkan pada kelas eksperimen mengalami peningkatan nilai rata-rata dengan selisih pretest dan posttest sebesar 34,33. Hal ini menunjukkan kelas eksperimen yang diberikan perlakuan berupa pembelajaran dengan menggunakan media simulasi memiliki peningkatan keterampilan berpikir kritis yang lebih tinggi daripada kelas kontrol yang diberikan perlakuan berupa pembelajaran konvensional.

Keterampilan berpikir kritis dalam penelitian ini merupakan keterampilan siswa dalam memberikan penjelasan sederhana, membangun keterampilan dasar, menyimpulkan, memberikan penjelasan lebih lanjut dan mengatur strategi dan taktik. 
Hasil keterampilan berpikir kritis siswa dapat dilihat dari Gambar 1 berikut.

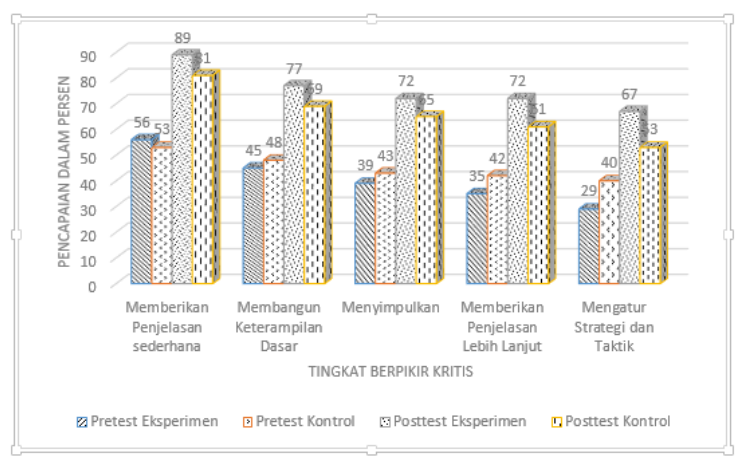

Gambar 1. Diagram Hasil Pretest dan Posttest Keterampilan Berpikir Kritis Siswa pada Kelas Eksperimen dan Kelas Kontrol.

Berdasarkan Gambar 1 di atas, terlihat bahwa hasil keterampilan berpikir kritis siswa secara keseluruhan, baik kelas eksperimen maupun kelas kontrol mengalami kenaikan. Kenaikan terjadi pada semua level apabila diurutkan dari yang tinggi hingga ke rendah, kenaikan tersebut berturut-turut terjadi pada kemampuan mengatur strategi dan taktik, memberikan penjelasan lebih lanjut,menyimpulkan, membangun keterampilan dasar dan memberikan penjelasan sederhana.

\section{Uji Hipotesis}

Setelah dilakukan uji normalitas dan homogenitas, selanjutnya dilakukan uji hipotesis untuk mengetahui pengaruh atau tidaknya media simulasi terhadap keterampilan berpikir kritis. Uji hipotesis menggunakan bantuan Software Statistical Product and Service Solutions (SPSS).

Berdasarkan Tabel 3, diperoleh informasi bahwa data pretest terdistribusi normal dan memiliki varian yang sama. Oleh karena itu, pengujian hipotesis dilakukan dengan menggunakan analisis tes statistik parametik berupa uji $\mathrm{T}$ sehingga hasil pretest sebelum diberikan perlakuan memiliki nilai Sig. (2-tailed) $(0,087)>$ taraf signifikansi $(\boldsymbol{\alpha})(\mathbf{0 , 0 5})$ maka dapat disimpulkan bahwa pada kegiatan pretest tidak terdapat pengaruh media simulasi terhadap keterampilan berpikir kritis siswa.

Tabel 3. Uji Hipotesis Data Pretest dan Posttest Kelas Eksperimen dan Kelas Kontrol.

\begin{tabular}{ccc}
\hline Statistik & Pretest & Posttest \\
\hline Sig. (2-tailed) & 0,087 & 0,001 \\
\hline Taraf Signifikansi & & 0,05 \\
\end{tabular}

$(\alpha)$

Kesimpulan $\quad \mathrm{H}_{\mathrm{o}}$ diterima $\mathrm{H}_{\mathrm{a}}$ diterima

Sementara, diperoleh informasi pula bahwa data posttest tidak terdistribusi normal dan memiliki varians yang sama, sehingga pengujian hipotesis dilakukan dengan menggunakan analisis tes statistik nonparametrik berupa uji Mann-Whitney sehingga hasil posttest setelah diberikan perlakuan memiliki nilai Sig. (2-tailed) $(0,001)<$ taraf signifikansi $(\boldsymbol{\alpha})(\mathbf{0 , 0 5})$, maka dapat disimpulkan bahwa kegiatan posttest terdapat pengaruh media simulasi terhadap keterampilan berpikir kritis siswa.

\section{Hasil Analisis Data Angket}

Analisis data angket pada penelitian ini dilakukan untuk mengetahui respon siswa terhadap penggunaan media simulasi. Hasil perhitungan analisis data angket respon siswa dapat dilihat pada Tabel 4.

Tabel 4. Hasil Angket terhadap Pembelajaran Menggunakan Media Simulasi.

\begin{tabular}{llcc}
\hline No. & $\begin{array}{c}\text { Indikator } \\
\text { Angket }\end{array}$ & Persentase & Kategori \\
\hline 1. & $\begin{array}{l}\text { Penyajian } \\
\text { Media Simulasi }\end{array}$ & $85 \%$ & Sangat Baik \\
\hline & $\begin{array}{l}\text { Pengaruh } \\
\text { Media Simulasi } \\
\text { terhadap } \\
\text { Keterampilan } \\
\text { Berpikir Kritis }\end{array}$ & $86 \%$ & Sangat Baik \\
2. & $86 \%$ & Sangat Baik \\
\hline
\end{tabular}


Berdasarkan Tabel 4 di atas, terlihat bahwa hasil angket respon siswa terhadap media simulasi, baik pada indikator penyajian media simulasi maupun pada indikator pengaruh media simulasi terhadap keterampilan berpikir kritis, terkategori sangat baik. Artinya, pembelajaran menggunakan media simulasi pada materi fluida statis secara keseluruhan mendapatkan respon positif.

\section{B. Pembahasan}

Berdasarkan hasil uji hipotesis data posttest, diperoleh nilai Sig.(2-tailed) sebesar 0,001 dengan taraf signifikansi sebesar 0,05. Artinya, nilai Sig.(2-tailed) < nilai taraf signifikansi, sehingga dapat disimpulkan bahwa terdapat pengaruh penggunaan media simulasi terhadap keterampilan berpikir kritis. Jika ditinjau berdasarkan nilai rata-rata posttest, kelas eksperimen memiliki nilai lebih tinggi dibandingkan kelas kontrol dengan selisih nilai sebesar 9,27. Hasil ini sejalan dengan hasil penelitian yang telah dilakukan oleh Zahara et al. (2015) yang menunjukkan bahwa rata-rata nilai siswa yang menggunakan media simulasi lebih tinggi dibandingkan siswa yang menggunakan pembelajaran konvensional. Peningkatan terlihat pada semua indikator, yaitu indikator memberikan penjelasan sederhana, membangun keterampilan dasar, menyimpulkan, memberikan penjelasan lebih lanjut dan mengatur strategi dan taktik.

Pada indikator memberikan penjelasan sederhana, kelas eksperimen lebih baik dibandingkan dengan kelas kontrol. Peningkatan yang paling signifikan terjadi pada sub indikator kemampuan menjawab pertanyaan klarifikasi. Hal ini dikarenakan media simulasi dilengkapi beberapa percobaan dan latihan soal yang mengajak siswa untuk dapat menjawab pertanyaan yang berkaitan dengan percobaan. Menurut Miftianiah et al. (2011) dalam penelitiannya menyatakan bahwa ketika siswa diberikan latihan soal, maka kemampuan menjawab pertanyaan dapat meningkat. Hal ini sejalan dengan penelitian yang dilakukan oleh Lestari et al. (2016) yang menyatakan bahwa ketika siswa diberikan permasalahan dalam bentuk latihan soal dan dituntut untuk dapat menyelesaikan permasalahan, secara tidak langsung kemampuan menjawab pertanyaan akan meningkat. Pernyataan ini sejalan dengan penelitian yang telah dilakukan oleh Latifa et al. (2017) keterampilan berpikir kritis tidak akan berkembang apabila tidak dilatih sehingga siswa membutuhkan latihan, praktik dan kesabaran.

Pada indikator membangun keterampilan dasar, kelas eksperimen lebih baik dibandingkan dengan kelas kontrol. Peningkatan yang paling signifikan terjadi pada sub indikator kemampuan menilai kredibilitas sumber. Hal tersebut karena media simulasi dilengkapi pertanyaan guna mengajak siswa untuk dapat memberikan alasan dengan benar. Pernyatan ini sejalan dengan penelitian yang telah dilakukan oleh Miftianiah et al. (2011) menginformasikan bahwa memberikan alasan yang sesuai dengan pertanyaan yang diperoleh dari informasi seperti buku, dapat meningkatkan kemampuan menilai kreadibilitas sumber. Hasil penelitian tersebut sejalan juga dengan penelitian yang dilakukan Ritdamaya (2016), memberikan informasi bahwa memberikan alasan dengan benar dapat meningkatkan kemampuan menilai kreadibilitas sumber dan juga dapat meningkatkan keterampilan berpikir kritis. Hasil ini juga sejalan dengan penelitian yang dilakukan oleh Pratiwi et al. (2019) yang menyatakan bahwa peserta didik dapat mengembangkan keterampilan berpikir kritis dengan dilatih menemukan sendiri pengetahuannya.

Pada indikator menyimpulkan, kelas eksperimen lebih baik dibandingkan dengan kelas kontrol. Pada indikator ini, salah satu sub indikatornya yang mengalami kenaikan, yaitu kemampuan induksi. Dalam hal ini 
media simulasi dilengkapi grafik yang mengajak siswa untuk dapat memberikan penilaian terhadap hubungan antara teori dengan percobaan. Hal ini sesuai dengan penelitian yang dilakukan oleh Ritdamaya (2011) yang memberikan informasi bahwa penilaian terhadap grafik dapat meningkatkan kemampuan induksi.

Pada indikator memberikan penjelasan lebih lanjut, kelas eksperimen lebih baik dibandingkan dengan kelas kontrol. Pada indikator ini, salah satu sub indikatornya yang mengalami kenaikan, yaitu kemampuan menilai definisi. Hal ini dikarenakan media simulasi dilengkapi percobaan yang mengajak siswa untuk dapat membuat definisi terhadap hubungan antara hasil percobaan dan teori. Sesuai dengan penelitian yang telah dilakukan oleh Ritdamaya (2016), yang menyatakan bahwa memberikan penilaian terhadap definisi yang telah dibuat dapat meningkatkan kemampuan dalam menilai definisi (Ritdamaya, 2016). Hal yang sama juga diungkapkan oleh Agustia et al. (2010), menyatakan bahwa membuat definisi dari percobaan dapat meningkatkan kemampuan dalam menilai suatu definisi dan juga meningkatkan kemampuan dalam berpikir kritis

Pada indikator mengatur strategi dan taktik, kelas eksperimen lebih baik dibandingkan dengan kelas kontrol. Pada indikator ini, salah satu sub indikatornya mengalami kenaikan yaitu menentukan tindakan. Hal ini dikarenakan media simulasi dilengkapi latihan soal dan mengajak siswa untuk dapat menentukan tindakan dalam menyelesaikan soal dengan benar. Sesuai dengan penelitian yang telah dilakukan oleh Pradana et al. (2017) yang menyatakan bahwa menyelesaikan soal dengan benar dapat meningkatkan kemampuan dalam menentukan suatu tindakan.

Hasil ini sejalan dengan penelitian yang telah dilakukan oleh Qurniati et al.
(2015) yang menyatakan bahwa menyelesaikan soal dengan baik dan benar dapat meningkatkan kemampuan berpikir kritis dan kemampuan dalam menentukan suatu tindakan.

\section{PENUTUP}

Berdasarkan hasil penelitian, dapat disimpulkan bahwa terdapat pengaruh penggunaan media simulasi terhadap keterampilan berpikir kritis siswa pada konsep fluida statis. Hal ini dapat dilihat pada hasil uji hipotesis statistik data posttest yang memberikan nilai Sig. (2-tailed) $(0,001)<$ taraf signifikansi $(0,05)$. Hasil $\mathrm{N}$-Gain juga memberikan informasi bahwa pembelajaran menggunakan media simulasi mengalami peningkatan. Peningkatan terlihat pada indikator memberikan penjelasan sederhana, membangun keterampilan dasar, menyimpulkan, memberikan penjelasan lebih lanjut dan mengatur strategi dan taktik. Empat diantara indikator tersebut mengalami peningkatan dengan kategori sedang, sementara satu indikatornya yaitu memberikan penjelasan sederhana mengalami peningkatan dengan kategori tinggi. Selain itu, penggunaan media simulasi pada pembelajaran mendapatkan respon positif dengan kategori sangat baik $(86 \%)$.

\section{REFERENSI}

Agustia, Z. Yennita \& Azizahwati. 2010. Implementasi Pembelajaran Hands On Activities untuk Meningkatkan Kemampuan Berpikir Kritis dalam Pembelajaran Fisika SMP. Jurnal Universitas Riau.

Arikunto, S. 2013. Prosedur Penelitian. Jakarta: Rineka Cipta.

Lestari, D. A. B., Astuti, B., \& Darsono, T. 2018. Implementasi LKS Dengan Pendekatan STEM (Science, Technology, Engineering, And Mathematics) Untuk Meningkatkan Kemampuan Berpikir Kritis Siswa. 
Jurnal Pendidikan Fisika dan Teknologi, 4(2), 202-207.

Latifa, B. R. A., Verawati, N. N. S. P., \& Harjono, A. 2017. Pengaruh Model Learning Cycle 5E (Engage, Explore, Explain, Elaboration, \& Evaluate) Terhadap Kemampuan Berpikir Kritis Peserta Didik Kelas X MAN 1 Mataram. Jurnal Pendidikan Fisika dan Teknologi, 3(1), 61-67.

Lestari, N., Edi, S. S., \& Hartono, H. 2016. Keefektifan Pembelajaran Problem Based Learning Berbantuan Pohon Masalah dalam Meningkatkan Kemampuan Berpikir Kritis Siswa SMP. UPEJ Unnes Physics Education Journal, 5(1).

Linn, R. L., Gronlund, N. E. 2008 Measurement and Assessment in Teaching, 10th Edition. USA: Prentice Hall.

Miftianah, N. N., Astuti, A. P., \& Hidayah, F. F. 2017. Analisis Keterampilan Berpikir Kritis Siswa Melalui Pembelajaran SETS Kelas X Pada Materi Larutan Elektrolit Dan Non Elektrolit. In Prosiding Seminar Nasional \& Internasional.

Peraturan menteri pendidikan dan kebudayaan Republik Indonesia Nomor 81 A Tahun 2013 tentang Implementasi Kurikulum Pedoman Umum Pembelajaran.

Pradana, S. D. S., Parno, P., \& Handayanto, S. K. 2017. Pengembangan tes kemampuan berpikir kritis pada materi Optik Geometri untuk mahasiswa Fisika. Jurnal Penelitian dan Evaluasi Pendidikan, 21(1), 5164.

Pratiwi, R., Hikmawati, H., \& Gunada, I. W. 2019. Pengaruh Model Pembelajaran Probing Prompting Berbantuan Video Terhadap Hasil Belajar Dan Kemampuan Berpikir Kritis Peserta Didik. Jurnal Pendidikan Fisika dan Teknologi, 5(2), 213-220.

Qurniati, D., Andayani, Y. \& Muntari. 2015. Peningkatan Keterampilan Berpikir
Kritis Melalui Pembelajaran Discovery Learning, Jurnal Penelitian Pendidikan IPA.

Zahara, S. R., Yusrizal, Y., \& Rahwanto, A. 2015. Pengaruh Penggunaan Media Komputer Berbasis Simulasi Physics Education Technology (PhET) Terhadap Hasil Belajar Dan Keterampilan Berfikir Kritis Siswa Pada Materi Fluida Statis. Jurnal Pendidikan Sains Indonesia, 3(1), 251-258

Ritdamaya, D. 2016. Konstruksi Instrumen Tes Keterampilan Berpikir Kritis Terkait Materi Suhu dan Kalor. Tesis Universitas Pendidikan Indonesia.

Sugiyono. 2011. Metode Penelitian Kuantitatif Kualitatif dan $R \& D$. Bandung: Alfabeta.

Wuri, O. R. \& Mulyaningsih, S. 2014. Penerapan Pendekatan Saintifik pada Pembelajaran Fisika Materi Kalor terhadap Keterampilan Berpikir Kritis Siswa Kelas X SMA. Jurnal Inovasi Pendidikan Fisika. 3(3). 